\title{
Performance Assessment of Modular Multilevel Half Bridge Inverter for High Power PV Application
}

\author{
P.Manimala, Sujatha Balaraman
}

\begin{abstract}
This paper presents three-level Modular Multilevel Half Bridge Inverter to achieve lower total harmonic distortion and improved efficiency. Compared to conventional inverter, multilevel inverters provide output voltage of high quality and current waveform while using the low switching frequency. The use of multilevel inverters reduces the switching losses, size of semiconductor switches and the number of harmonic filters as compared to the traditional DC-AC inverters. This paper investigates different classification of multilevel inverters suitable for photovoltaic applications of high power based on efficiency and THD of the output line voltage and current waveform. Multilevel Inverter topologies are simulated as the same environment using MATLAB/Simulink.
\end{abstract}

Keywords:

Multilevel

Inverter

(MLI),

Neutral-Point-Clamped Inverter (NPCI), Capacitor Clamped -Multilevel Inverter (CC-MLI), Cascaded H-bridge Inverter (CHB-MLI), Modular Multilevel Half Bridge Inverter (MMLHBI), Total Harmonic Distortion (THD).

\section{INTRODUCTION}

Generation of electric power from renewable energy sources are growing trends in recent years. At the same time, a sudden increase in the power rating of wind turbines, photovoltaic power plants and other renewable equipment has been observed [1]. The Power electronics devices are utmost important to produce a great variety of products in recent years. Multilevel Inverters has gaining more attention in recent years. It has numerous advantages compared to conventional DC-AC inverters. A few advantages of multilevel inverters are, they can generate voltage at many levels with extremely very low distortion therefore reduced $\mathrm{dv} / \mathrm{dt}$ stress, reduced harmonics and lower the electromagnetic compatibility problems, and also it can be operated with lower switching frequency. Multilevel Inverter produces reduced harmonics and stepped output waveform with high quality. The quality of the waveform is improved by the Pulse Width Modulation techniques. Proper selection of the Modulation techniques is very important in Multilevel

Revised Manuscript Received on November 27, 2019.

* Correspondence Author

P.Manimala, Department of Electrical and Electronics Engineering, manimala.gopalakrishnan@gmail.com

Dr.Sujatha Balaraman, Department of Electrical and Electronics Engineering, Government College of Technology, Coimbatore, India. Email: sujathaeee@gct.ac.in Government College of Technology, Coimbatore, India. Email:

Inverters [2]. Neutral-Point- Clamped Inverter or diode-clamped inverter [3], Capacitor Clamped- Multilevel Inverter (Flying Capacitor inverter) [4] and Cascaded H-bridge Multilevel Inverter [5] are the most common topologies of multilevel inverter.

In a diode-clamped inverter, balancing the capacitor voltage remains as a critical problem in high levels. When the level increases, the use of power semiconductor devices gradually increase and the realization of the inverter become difficult [6]. The CC-MLI topology uses several clamping capacitors as a replacement for of clamping diodes in NPCI. This topology has been used single DC source and the capacitor voltage balancing has been attained by use of switching redundancy within the phase. In real power transmission switching, utilization and efficiency of the CC-MLI are poor and it require a greater number of clamping capacitors, so it is more expensive and voltage tracking of the capacitor is complex [7].

The CHB topology is more suitable for high power usage capacity and consistency than other conventional multilevel inverters due to the modular structure. This inverter requires huge number of seperated dc sources for each H-Bridges of CHB-MLI that are generally given by a bulky, multi winding transformer along with rectifiers and to reach higher voltage levels is a challenge for semiconductor technology, increasing the blocking voltage and other related technologies like gate drivers and sensors and numbers of semiconductor devices [6-9].

Among the MLI topologies Modular Multilevel Half Bridge Inverter (MMLHBI) was proposed to overcome the drawbacks of conventional multilevel inverters. Some of the features of MMLHBI are modular structure, simple realization, redundancy, an inverter built up by modules and it can be easily scaled to different voltage and power levels so that it has a modular realization and the harmonic distortion reduces when the number of level increases. The inverter can continue to operate, even though some of the components experience failure. Also, it is better in managing the fault [10]. The modular construction of MMLHBI reduces investment and life cycle cost with the use of standard components [11].

The outline of this paper is as follows. The basic structure and operating principle of different Multilevel Inverter topologies are specified in Section 2. 


\section{Performance Assessment of Modular Multilevel Half Bridge Inverter for High Power PV Application}

In section 3, simulink model of various MLI topologies are discussed based on the efficiency and THD of output line voltage and current waveform. Finally the validity of the MLI is verified by MATLAB/ Simulink simulation cases in section 4. The conclusion of the work is summarized in section 5 .

\section{MULTILEVEL INVERTER TOPOLOGIES}

Multilevel inverter is to convert DC to AC. From batteries, solar panel, and wind turbine or in fuel cells the inverter plays a major role. In modern technology, Power electronics is very important to produce a great variety of products. Multilevel Inverters has gained wide attention in recent years.

\section{A. Diode Clamped-Multilevel Inverter}

Three-level diode clamped MLIs are often known as Neutral-Point- Clamped Inverters (NPCI). It is used in high power voltage drives applications. Some of the main features of NPCI are they do not have dynamic voltage sharing problem, they possess static voltage equalization without using additional components and also they have reduced harmonic distortion and dv/dt stress [12]. The special controller is required to balance the capacitor voltages.

Figure 1 shows the circuit diagram of NPCI. The circuit has four switches per phase. Each phase consists of an upper and a lower leg. The lower leg switches Sx1' and Sx2' are the complementary of upper leg switches $\mathrm{Sx} 1$ and $\mathrm{Sx} 2$, where $\mathrm{x}$ is any of the phases $\mathrm{a}, \mathrm{b}$ or $\mathrm{c}$. The switches are connected in series. The diodes Dc and Dc' are clamping diodes and is used to connect the neutral $\mathrm{N}$ to the midpoint of the each leg.

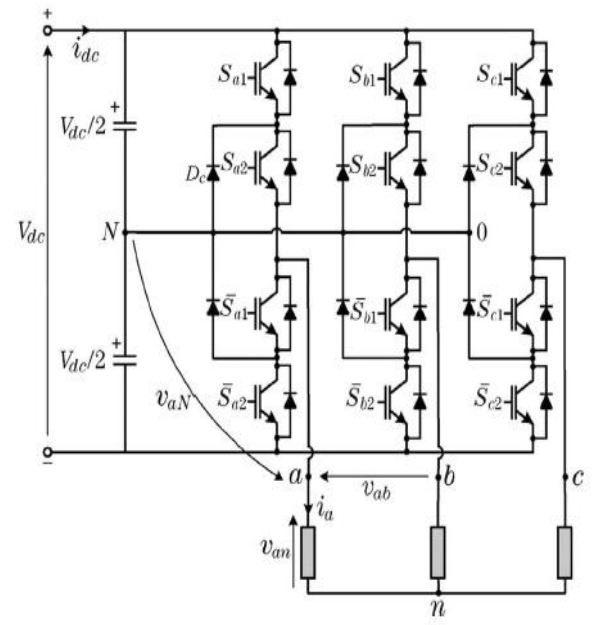

Fig.1 Three-level Diode Clamped-Multilevel Inverter

Table-I: Switching State of Three-Level NPCI

\begin{tabular}{|c|c|c|c|c|}
\hline \multicolumn{4}{|c|}{ Switching Devices } & \multirow{2}{*}{$\begin{array}{l}\text { Output } \\
\text { Voltage }\end{array}$} \\
\hline$S x 1$ & $S \times 2$ & $S \times 1$ & $S \times 2$ & \\
\hline 1 & 1 & 0 & 0 & $\mathrm{Vdc} / 2$ \\
\hline 0 & 1 & 1 & 0 & 0 \\
\hline 0 & 0 & 1 & 1 & $-\mathrm{Vdc} / 2$ \\
\hline
\end{tabular}

The clamping diodes are connected to the neutral bus; control the voltage distribution among the four IGBTs in each phase leg. In this inverter, the voltage drop across each switch is one half of the voltage between the positive and negative bus.

Table.1. shows the switching states of the three-level NPCI. This topology produces five-level in the output line-to-line waveforms and three-level in the line-to-neutral waveforms. The output is tapped from the mid-point of each arm comprising of four IGBTs are connected in series. The mid-point of the DC bus is shown by symbol $\mathrm{N}$ and is connected between a pair of series connected diodes in each phase.

\section{B. Capacitor Clamped-Multilevel Inverter}

The CC-MLI was invented by Meynard and Foch in 1992. The design of this inverter is same as diode-clamped inverter where in a capacitor is used as a substitute for clamping diodes is appear in figure 2. CC-MLI has a ladder structure comprised of DC side capacitors, where the voltage on each capacitor diverges from the other. The stepped output voltage waveform of this inverter is given by voltage increment between two adjacent clamping capacitors. The CC-MLI does not entail all the switches in conductive states unlike diode-clamped inverter. The capacitor voltage level balancing of this inverter is attained by the phase redundancies and also active and reactive power flow can be controlled [13]. Pre-charging of all capacitors to the same voltage level is a tedious process. Real power transmission has meager switching utilization and efficiency. Presence of huge number of capacitors make it more opulent and healtier in comparison with multilevel diode-clamped converters [6].

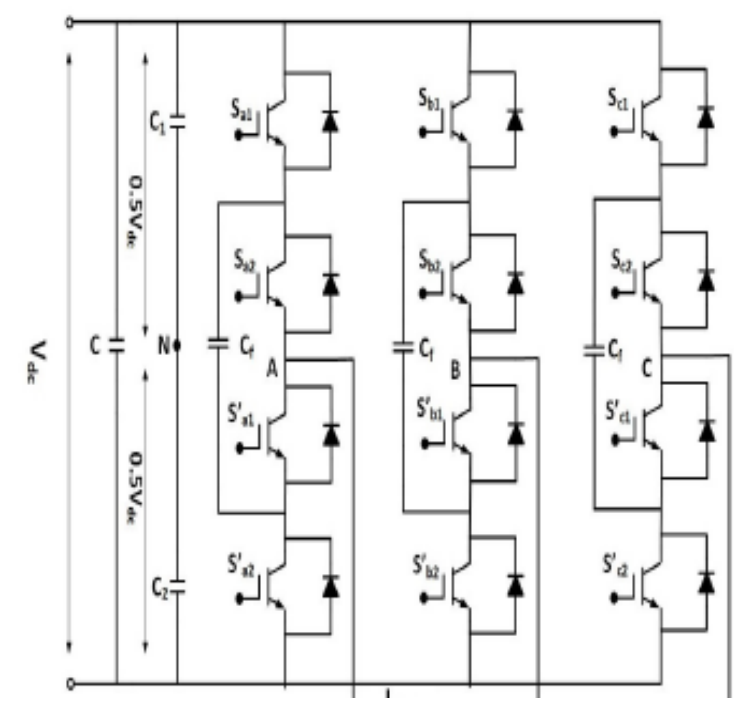

Fig.2 Three-phase three-level Capacitor Clamped-Multilevel Inverter

\section{Cascaded H-Bridge Multilevel Inverter}

The CHB-MLI is consists of power cells connected in series. The power cell contains an H-bridge inverter each H-bridges supplied by a 
separate dc-sources. Each $\mathrm{H}$-bridge cell can produce $+\mathrm{Vdc}, 0$, -Vdc. CHB-MLI required reduced number of switching components, when compared with diode clamped and flying capacitor inverters and also absence of clamping capacitors and clamping diodes these are the major advantages of this inverter. The cascade topology allows the utilization of $\mathrm{dc}$ sources with variable voltage values, and high-resolution multilevel stepped nearly sinusoidal waveforms can be attained with a fairly reduced number of components [14]. The structure of the three phase Cascaded Multilevel Inverter topology is shown in figure 3 .

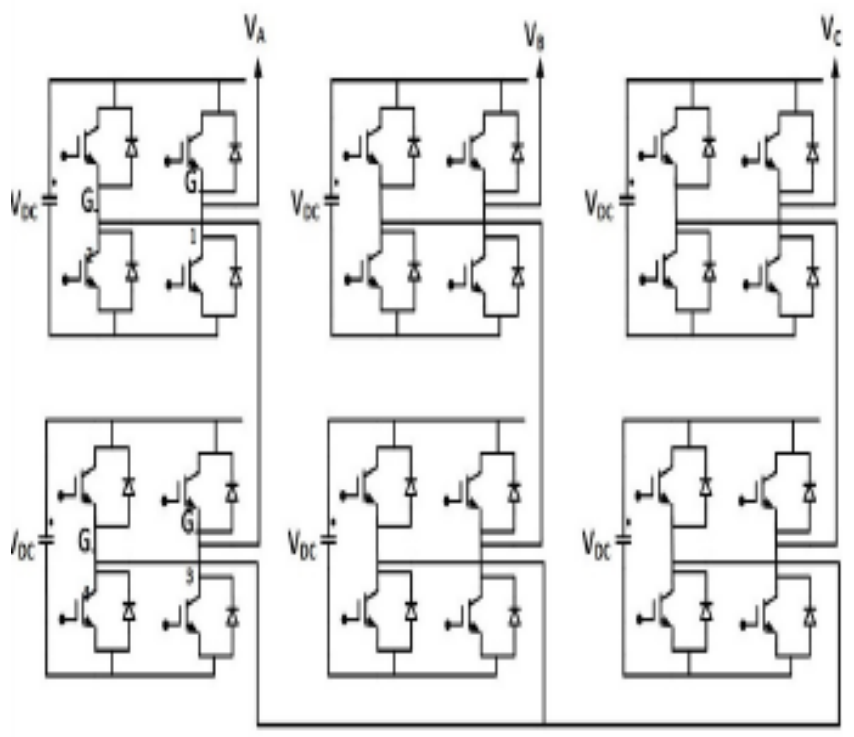

Fig.3 Three-phase Cascaded H-Bridge-Multilevel Inverter

\section{Modular Multilevel Half Bridge InVerter}

The MMLHBI is the most advanced power converter topology proposed in 2002. It uses modular structure to achieve higher level output voltages with reduced harmonics, thus it is widely promoted, especially for high voltage and high-power implementations such as HVDC, Variable voltage AC drives and it is also widely accepted in the industries.

Basic Circuit structure of three-level MMLHBI:

Figure.4. shows structure of the three-phase MMLHBI. The power circuit has eight switches per phase. Each phase consists of upper and lower arm. Each arm is the cascaded connection of sub-modules (SMs) or cells, usually made of Half-bridges [15, 16, 17]. The SM has two semiconductor devices such as main switch $S_{m}$ and an auxiliary switch $S_{a}$ are cascaded and a capacitor in parallel. This capacitor is called as sub-module capacitor. The auxiliary switches are complementary of the main switches.

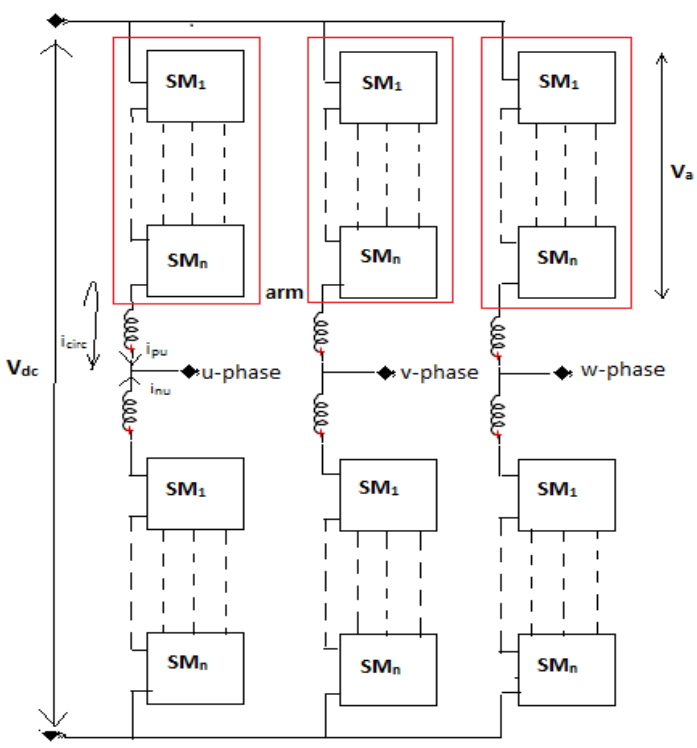

(a)

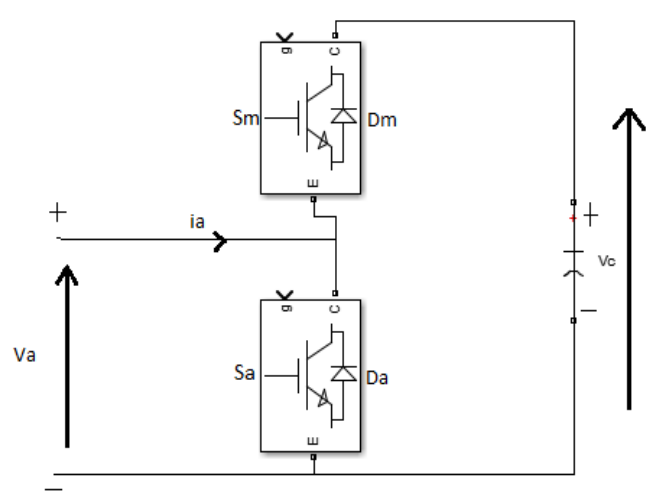

(b)

Fig.4 (a) Structure of Three Phase Modular Multilevel Inverter (b) Half Bridge Sub module

A three-level MMLHBI has two sub-modules in upper arm and two sub-modules in lower arm these are connected by the arm inductance. In normal operation, the arm inductance is used to protect the switches from the inrush current caused by the capacitors as well as to limit the circulating current. An arm inductance is incorporated to isolate the upper arm and lower arm from the circulating current. The output current ripples are filtered out by use of arm inductor [18]. By switching the sub modules on and off at the right time, the voltage can be developed stepwise, producing nearly a sinusoidal shaped output voltage or current. The switching states for three-level modular multilevel inverter described in table2.

Table-II: Switching Combination for a Three-Level MMLHBI

\begin{tabular}{|l|l|l|l|l|l|l|l|l|}
\hline \multirow{2}{*}{$\begin{array}{l}\text { Output } \\
\text { Voltage }\end{array}$} & \multicolumn{4}{|l|}{ Main Switches $($ Sm $)$} & \multicolumn{4}{c|}{ Auxiliary Switches (Sa) } \\
\cline { 2 - 10 } & Sm1 & Sm2 & Sm3 & Sm4 & Sal & Sa2 & Sa3 & Sa4 \\
\hline Vdc/2 & 1 & 1 & 0 & 0 & 0 & 0 & 1 & 1 \\
\hline \multirow{3}{*}{0} & 1 & 0 & 1 & 0 & 0 & 1 & 0 & 1 \\
\cline { 2 - 9 } & 0 & 1 & 1 & 0 & 1 & 0 & 0 & 1 \\
\cline { 2 - 9 } & 0 & 1 & 0 & 1 & 1 & 0 & 1 & 0 \\
\cline { 2 - 9 } & 1 & 0 & 0 & 1 & 0 & 1 & 1 & 0 \\
\hline$-\mathrm{Vdc} / 2$ & 0 & 0 & 1 & 1 & 1 & 1 & 0 & 0 \\
\hline
\end{tabular}




\section{Performance Assessment of Modular Multilevel Half Bridge Inverter for High Power PV Application}

\section{RESULTS AND DISCUSSION}

In this study, three phase, three-level Modular Multilevel Inverter topology was considered, which is connected to PV array and its performance was analyzed in terms of Total harmonic distortion of phase voltage, line voltage and line current, efficiency was simulated in MATLAB- Simulink environment. Canadian solar CS5C90M is used as the PV array module comprised of 40 parallel strings and 10 series connected modules per strings, with an irradiation of 1000 $\mathrm{W} / \mathrm{m}^{2}$, temperature of $25^{\circ} \mathrm{C}$ and a three-phase resistive load of $\mathrm{R}=10 \Omega$.

\section{A. Modular Multilevel Half Bridge PV Source Inverter}

The Modular multilevel inverter with Photovoltaic power system is simulated with MATLAB/SIMULINK Software is shown in figure 5 . The photovoltaic arrays composed of 40 numbers of cells are connected in series to form a module and 10 modules connected in series to generate voltage of $222 \mathrm{~V}$.

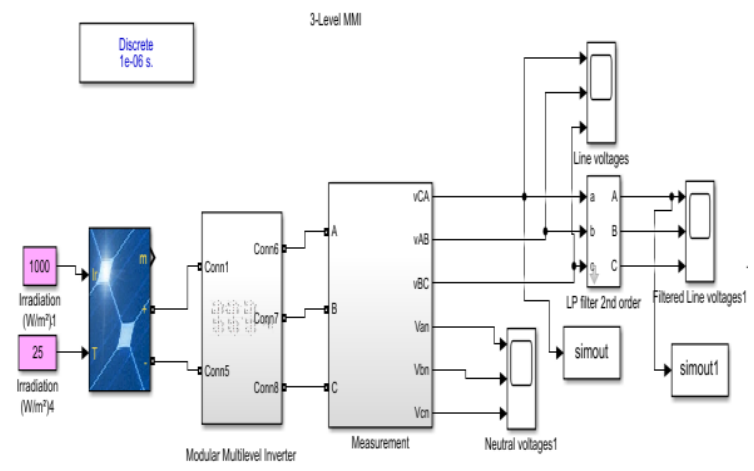

Fig.5 Simulink Model of Three-level MMLHBI PV source inverter
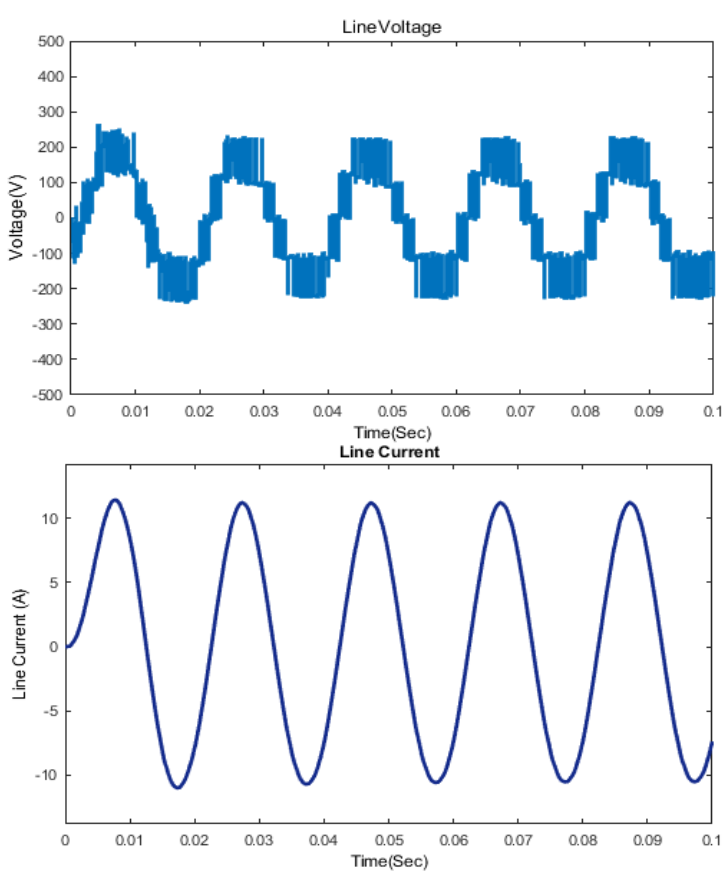

Fig.6 Output waveform of three-level MMLHBI

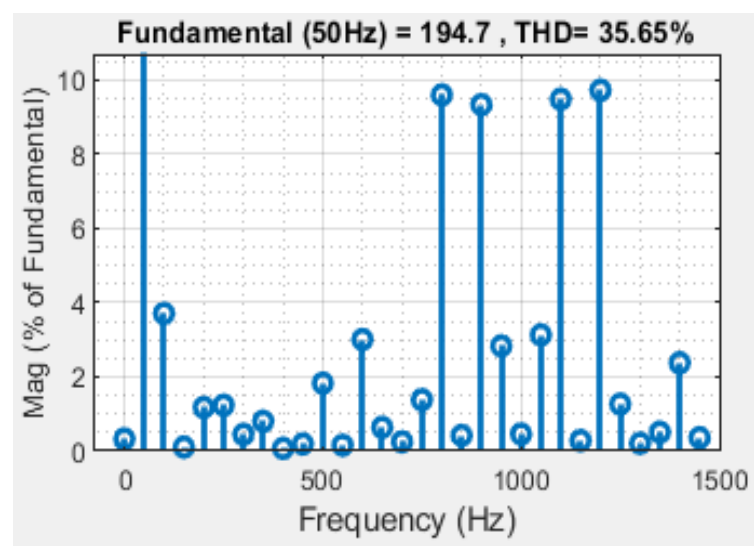

Fig.7 FFT Spectrum of Line voltage of three-level $M M L H B I$

In this case sub-module capacitors are considered as $170 \mu \mathrm{F}$ and the identical PV module are used for the simulation. Output line voltage, current waveform and FFT spectrum of Line voltages are shown in figure 6 and 7. THD of the line voltage is found to be $35.65 \%$ and the efficiency obtained as $99.72 \%$

Table-III: Comparison of various Multilevel Inverter Topologies

\begin{tabular}{|l|l|l|l|}
\hline S.No. & $\begin{array}{c}\text { Multilevel Inverter } \\
\text { Topology }\end{array}$ & $\begin{array}{c}\text { Efficiency } \\
(\%)\end{array}$ & $\begin{array}{c}\text { Line Voltage } \\
\text { THD (\%) }\end{array}$ \\
\hline 1 & $\begin{array}{l}\text { Cascaded H-Bridge } \\
\text { MLI [Ref, 21] }\end{array}$ & 83.88 & 47.18 \\
\hline 2 & $\begin{array}{l}\text { Capacitor Clamped } \\
\text { MLI [Ref, 21] }\end{array}$ & 98.65 & 49.89 \\
\hline 3 & $\begin{array}{l}\text { NPC MLI [Ref, 21] } \\
\text { Modular Multilevel } \\
\text { Inverter (Proposed) }\end{array}$ & $\mathbf{9 9 . 7 2}$ & $\mathbf{3 5 . 6 5}$ \\
\hline
\end{tabular}

The performance of various MLI Topologies is summarized in Table.3. When compared to other MLI inverter topologies, Cascaded MLI does not require clamping capacitors and clamping diodes. The major disadvantage of cascaded MLI, individual DC source is required for each $\mathrm{H}$-Bridge. Hence it reduces the overall efficiency of the system and THD of line voltage was to be found to be $83.88 \%$ and $47.18 \%$ respectively.

The next inverter is capacitor clamped MLI topology, which is identical to the diode clamped inverter. The major difference is the use of clamping diodes, which is used for reverse voltage protection [20]. Another inverter topology is NPCI, provides multilevel output voltage through the different phases to the capacitors, which are connected in series. In NPCI, the switching stresses of electrical devices are limited by the use of clamping diodes. The maximum voltage of the NPCI is Vdc/2; this is main disadvantage of NPCI. The major drawback of NPCI is that the maximum voltage of NPCI is $50 \%$ of input DC voltage. These problems are resolved by increasing the number of switching devices, diodes and capacitors. Therefore, Diode Clamped Multilevel Inverters are limited to lower than five levels [19].

Among the MLI topologies, MMLHBI has a modular structure and the ability to solve problems such as high voltage across the capacitors and high stress on power switches. 
MMLHBIs are built up by similar, but individually controllable sub-modules. The half bridge sub-module prevents the generation harmonic content and it acts as a controllable voltage source inverter. In addition, the efficiency of the MMLHBI is superior among other categories of multilevel inverters. As it can be inferred from the table, the efficiency of NPCI and MMLHBI was slightly varying. However, NPCI inverters are limited to lower than five levels. Therefore, when number of level increases, NPCI is not appropriate for high power and high voltage applications. From simulation it is revealed that MMLHBI outperforms over other MLI in terms of efficiency and THD of the output voltage and current waveforms. MMLHBI is right choice for high power and high voltage applications as inferred from the simulation. The THD in line voltage and efficiency were found to be $35.65 \%$ and $99.72 \%$.

\section{CONCLUSION}

Multilevel inverter topology has several advantages compared to conventional DC-AC inverter and MLI is more economical compared to two-level inverter. In this paper different classification of multilevel inverters are investigated under same environment in MATLAB/Simulink environment. Four multilevel inverter topologies are discussed and the comparisons were done based on the THD, efficiency in order to select the most suitable inverter topology for high power applications. It is found that Modular Multilevel inverter produces better harmonics and efficiency than other inverter topologies. The simulation results prove that MMLHBI is more suitable for high power applications.

\section{REFERENCES}

[1] S. Chakraborty, M. G. Simoes, W. E. Kramer, Power Electronics for renewable and distributed energy systems", Springer, 2013.

[2] Lai J.S., Peng F.Z.: 'Multilevel converters-a new breed of power converters', IEEE Transaction on Industrial Application,Vol.32, No.3, pp. 509-517, 1996.

[3] Jose Rodriguez, Peter K. Steimer, Ignacio E. Lizama, "A Survey on Neutral-Point Clamped Inverters", IEEE Transaction on Industrial Electronics, Vol.57, No.7, 2010.

[4] M. F. Escalante, J. C. Vannier, and A. Arzande, "Flying capacitor multilevel inverters and DTC motor drive applications," IEEE Transaction on Industrial Electronics, Vol. 49, No. 4, pp. 809-815, Aug. 2002.

[5] Yasmeena, Dr.G. Tulasi Ram Das, "Cascaded Multilevel Inverter: A survey of Topologies, Controls, and Applications", International Journa of Scientific \& Engineering Research, Vol.4, Issue 8, pp: 353-367, 2013.

[6] Richard Castillo, BillDiong, Preston Biggers, "Single phase hybrid cascaded H-Bridge and Diode Clamped Multilevel Inverter with capacitor voltage balancing", IET Power Electronics, Vol.11, No.4, pp-700-707, 2018

[7] M. F. Escalante, J. C. Vannier, and A. Arzande, "Flying capacitor multilevel inverters and DTC motor drive applications," IEEE Transaction on Industrial Electronics., Vol. 49, no. 4, pp. 809-815, Aug. 2002.

[8] Babaei E. "A cascade multilevel converter topology with reduced number of switches", IEEE Transaction on Power Electronics, Vol.23, No.6,pp-2657-64, 2008.

[9] Mariusz Malinowski, K Gopakumar, Jose Rodriguez, Marcelo A Perez, A survey on Cascaded Multilevel Inverters", IEEE Transaction on Industrial Electronics, Vol.57, No.7, pp. 2197-2206, 2010.

[10] Kavitha S Nair, Jaison Mathew, "Capacitor balancing of a Modular Multilevel Inverter using a Modulation strategy", International conference on Nesxt generation Intelligent systems (ICNGIS), 2016.
[11] Hirofumi Akagi, "Classification, terminology and application of the Modular Multilevel Cascaded Converter (MMCC)", IEEE Transaction on Power Electronics, Vol.26, No.11, pp.3119-3130, Nov 2011.

[12] Haibing Hu, Wenxi Yao, Yan xing and Zhengyu Lu, "A generalized algorithm of n-level space vector PWM suitable for hardware implementation", Proceeding of the IEEE Power Electronics specialists conference, pp.4472-4478, 2008

[13] M. Madhu Shobini, J Kamala, R. Rathna,“ Analysis and simulation of Flying Capacitor Multilevel Inverter using PDPWM strategy", International Conference on Innovative Mechanisms for Industry Applications (ICIMIA), 2017

[14] Asha Gaikwad, Pallavi Appaso Arbune, "Study of Cascaded H-Bridge multilevel inverter", IEEE International conference on Automatic Control and Dynamic Optimization Techniques, 2017

[15] T.Yuvaraja, Somnath Mazumder, -Performance and Analysis of Modular Multilevel Converter.l AJER, Vol. 3, issue-01,pp 1-8,2014

[16] Manish V. Kurwale, Palak G. Sharma, Gautam Bacher, "Performance Analysis of Modular Multilevel Converter (MMC) with Continuous and Discontinuous Pulse Width Modulation (PWM)", IJAREEIE, vol.3, issue. 2, Feb 2014

[17] Solas, G. Abad, J. Barrena, S. Aurtenetxea, A. Carcar and L. Zajac, "Modular Multilevel Converter with different submodule concepts- Part II: Experimental validation and comparison for HVDC application", IEEE Transaction on Industrial Electronics, Vol.60, No.10, pp-4536-4545, 2013

[18] Hirofumi Akagi, "Classification, terminology and application of the Modular Multilevel Cascaded Converter (MMCC)", IEEE Transaction on Power Electronics, Vol26, No.11, pp: 3119-3130, 2011

[19] H. Abu-Rub, M. Malinowski, K. Alhaddad, " Power electronics for Renewable Energy Systems", transportation and industrial applications, John Wiley \& Sons Ltd, A co-publication of IEEE Press, 2014.

[20] Subhashree Choudhury, Samikhya Nayak, Tara Prasanna Dash, P K Rout, "A Comparative Analysis of Five level Diode Clamped and Cascaded H-Bridge Multilevel inverterfor Harmonic Reduction", IEEE International Conference on Technologies for Smart-City Energy Security and Power, 2018.

[21] A Delavari, I Kamwa, A Zabihinejad, "A Comparative Study of Different Multilevel Converter Topologies for High Power Photovoltaic Applications", $7^{\text {th }}$ Power Electronics, Drive Systems \& Technologies Conference (PEDSTC), 2016

\section{AUTHORS PROFILE}

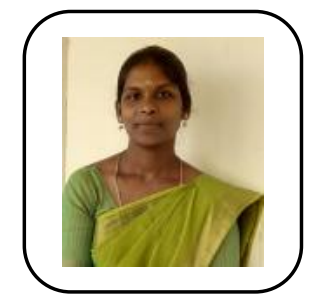

P Manimala received her B.E. degree in 2010 and M.E. degree in 2015 from Anna University, Chennai. She is presently pursuing Full-Time $\mathrm{Ph} . \mathrm{D}$. degree in the Department of Electrical and Electronics Engineering, Government College of Technology, Coimbatore. Her research interests include, Multilevel Inverter topologies, power electronic

Rectifiers and Resonant converters.

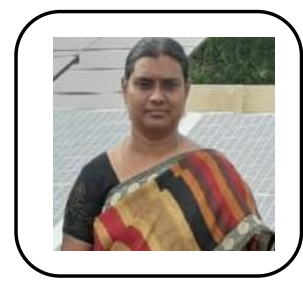

Dr.Sujatha Balaraman received her Ph.D degree in Faculty of Electrical Engineering from Anna University, Chennai in 2012. She is currently working as Associate Professor in the Department of Electrical and Electronics Engineering, Government College of Technology, Coimbatore. Her research interests include Power systems operation and control, Soft Computing Techniques and Inverters. 